\title{
The Story of Life's Quality of Patients with Hypertentions and Its Complication
}

\author{
Amelia Rumi ${ }^{1}$, Rudi Safarudin ${ }^{1,2}$, Ririen Hardani ${ }^{1}$, Dwi She Dewi Melinency B ${ }^{1}$, Nur Indah Sari ${ }^{1}$, Khildayanti S \\ Lilies Handayani ${ }^{3}$, Nurulhuda Rahman ${ }^{3}$, Ismail Setyopranoto ${ }^{4}$ and Sitti Rahmawati ${ }^{5}$
}

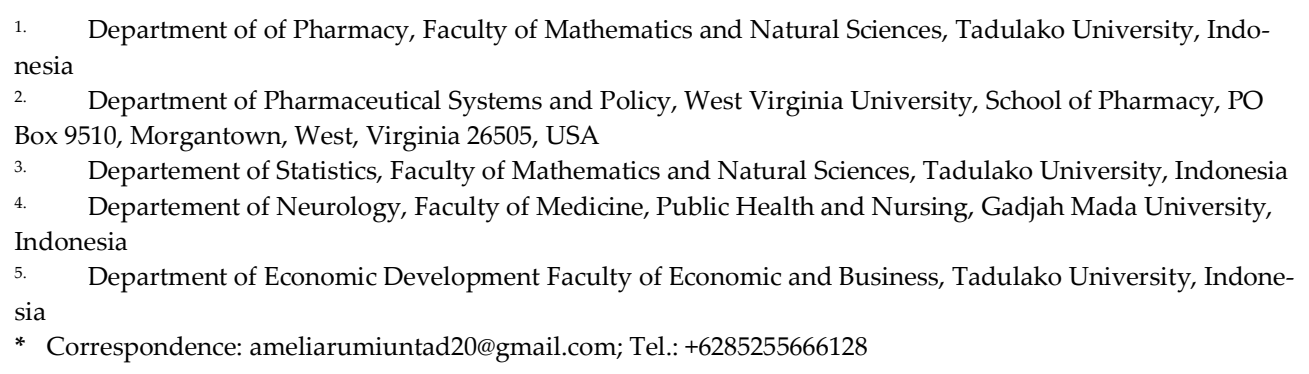

\begin{abstract}
The aim of this study as to determine the relationship between the factors of demography, comorbidity, medication, lifestyle, and access to health services related to the QoL of people with hypertension and its complications in Sleman Regency, Yogyakarta. The study was conducted in a cross-sectional manner using data from Sleman HDSS (Health and Demographic Surveillance System) from 2015 to 2018 in cycles 3 and 2 with the inclusion criteria of hypertensive patients and their complications aged 25 years or older obtained by using a total sampling of 532 people. Measurement of QoL using Short Form 12v2 2a and 2b questionnaires presented in the Physical Component Summary (PCS) and Mental Component Summary (MCS). Data analysis using Mann-Whitney test and Kruskal Wallis test. The results showed factors related to the QoL in PCS were variables of gender, age, diagnosis of hypertension and its complications, the presence of comorbidities, fatty foods, drug consumption in the last two weeks, while factors related to the mental component (MCS) were education and occupation seen from the $p$-value $<0.05$. QoL with hypertension and its complications influence and decrease the physical than the patient's mental condition.
\end{abstract}

Keywords: Hypertension management; Complications of cardiovascular; Quality of Life

\section{Introduction}

Hypertension is a condition when the pressure on the arteries increases persistently [1]. The normal blood pressure is $120 / 80 \mathrm{mmHg}$, and it is said to be hypertensive if the systolic blood pressure is $\geq 130 \mathrm{mmHg}$ and diastolic blood pressure is $\geq 80 \mathrm{mmHg}$ [2], [3].

According to study, hypertension was 8.4 percent of the population aged 18 years diagnosed by doctors in Indonesia in 2018, a reduction of $1 \%$ from 2013. The majority of hypertension for women is more significant, namely $36.9 \%$, than men, only $31.3 \%$. Yogyakarta Special Region was the 4th most diagnosed hypertension by doctors [4], [5].

Heart disease and stroke are among the two leading causes of death in the world. Stroke, heart failure and kidney disease are the main risk factors for hypertension. Therefore, hypertension is a health problem that is considered quite dangerous in the world [6]. According to the American Heart Association (AHA), people with hypertension in the American population aged 20 years and overreached 74.5 million people [7]. Indirectly, hypertension can affect the heart through changes in blood vessels, namely atherosclerosis. Atherosclerosis can cause cardiovascular disease and increase the risk of ischemic events, such as angina and myocardial infarction. Hypertension can also affect the heart directly through the pressure effect of hypertension [8]. The pressure effect of 
hypertension leads to left ventricular hypertrophy, which becomes myocardial and not arterial changes. In response to increased resistance due to increased blood pressure, a cardiac compensatory method is left ventricular hypertrophy. Hypertrophy is a risk factor for coronary heart disease [9], [10].

Environmental risk factors, namely the interaction of genes with the environment, age, changes in blood vessels, and demographic and socioeconomic substantial risk factors for hypertension, can lower blood pressure, such as changes in lifestyle, smoking habits, choice of drugs, and correct dosage. QoL is the perception of individuals based on their position in life, seen from the culture and value system, where they live concerning their hopes, goals, standards and problems. This is influenced in a complex way by their physical health, personal beliefs, psychological state, social relationships and relationships from their environment [11] [12], [13].

Hypertensive patients have more complex health care needs than normotensive people. Several studies have described hypertension as causing severe damage to Health-Related QoL (HRQoL). Based on several observational studies, it can be concluded that hypertension can reduce HRQoL, but the amount is small [14], [15].

According to the results of the psychometric property assessment of the health-related QoL (HRQoL) instrument in the general population, the SF-12 tool is one of the categories of means that are assessed as an established instrument [16], [17]. Therefore, based on the description above, the researcher aimed to conduct research observations on factors, such as demography, comorbidities, lifestyle, medication and access to health services, that can affect the QoL of hypertensive patients in Sleman Regency, Yogyakarta by using data (Health and Demographic Surveillance System/HDSS) in Sleman with a 12v2 Short Form Questionnaire Instrument consisting of 8 domains.

\section{Materials and Methods}

The study was approved by the Medical and Health Research Ethics Committee Faculty of Medicine, Public Health and Nursing, Gadjah Mada University, with reference number: KE/FK/1253/EC/ 2020.

The study uses secondary data on the HDSS (health and surveillance system) Sleman in 2015-2018. Where researchers participate in research using that data. Where the data are drawn are the demographic data of individuals (gender, age, marital status, education and work), comorbidities (stroke, pneumonia, diabetes mellitus, and angina), lifestyle factors (fatty foods and smoking), and medical factors (old medicine). That is, the last two weeks and the last 12 months), as well as access to health services (the place for treatment and payment) as an independent factor, while dependency is the QoL using the SF-12v2. Then sampling retrieval uses purposive sampling. According to the population of longitudinal HDSS Sleman surveillance research, hypertension was recorded, and complications were made into a sample in the study of 532 respondents who met the criteria of inclusion (aged $>25$ years and lack of disability) and filled out the complete questionnaire. In contrast, incomplete respondents filled out the data released from the research. As for the QoL that is measured in this study divide into two components and make up into eight domains:

Table 1. Summary of Short Form 12v2 Instruments Two Components.

\begin{tabular}{cc}
\hline Physical Component Summary (PCS) & Mental Component Summary (MCS) \\
\hline Physical Function & Vitality \\
Physical Role & Social Position \\
Body Aches & Emotional Role \\
\hline General Health & Mental Health \\
\hline
\end{tabular}




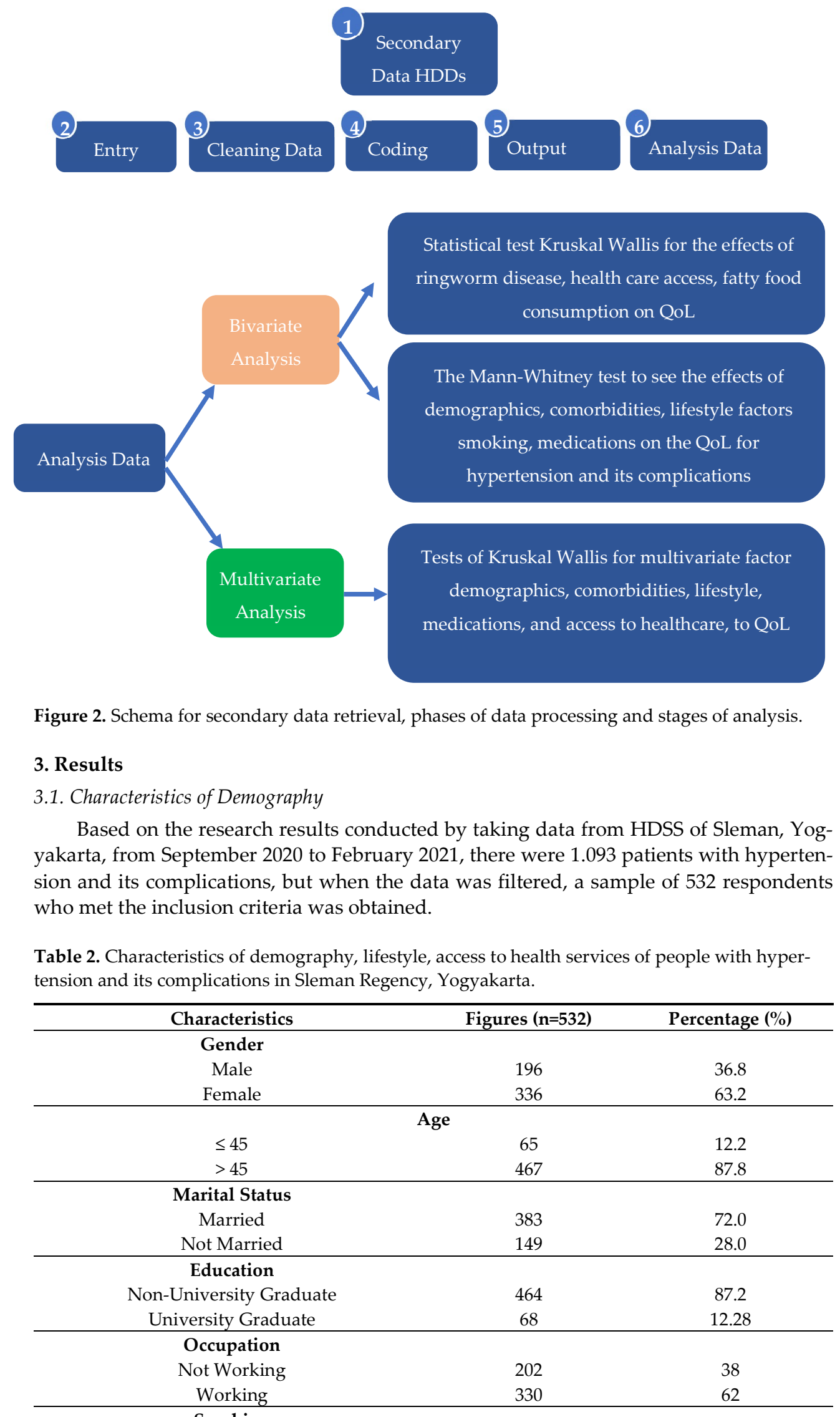

Smoking 


\begin{tabular}{ccc} 
No & 475 & 89.3 \\
Yes & 57 & 10.7 \\
\hline Consumption of Fatty Foods & 262 & 49.2 \\
Everyday & 106 & 19.9 \\
1x-2x a week & 65 & 12.2 \\
3x-6x a week & 99 & 18.6 \\
<3x a month & & \\
No & 288 & 54.1 \\
Yes & 244 & 45.9 \\
\hline Getting treatment in the last 12 weeks & & \\
Yes & 189 & 35.5 \\
Getting treatment in the last 12 montha & 343 & 64.5 \\
\hline Po & 159 & 29.9 \\
Public Hospital/Puskesmas & 89 & 16.7 \\
Private Hospital & 187 & 35.2 \\
Health Worker Practice & 97 & 18.2 \\
Others & & 46.1 \\
Payment Method & 245 & 37.2 \\
Insurance & 198 & 16.7 \\
\hline Independently & 89 & \\
No Treatment & & \\
\hline
\end{tabular}

Based on Table 2 above, the distribution of respondents with hypertension based on gender was dominated by 336 female patients $(36.8 \%)$, which was higher than the male patients, which only 196 (36.8\%). Meanwhile, the majority of patients with hypertension and its complications occurred at the age above 45 years, with the married status of 383 (72\%) patients, with no university degrees of 464 patients, which was the highest, and with the working status of $383(72 \%)$ patients, in average. Based on the distribution of respondents' lifestyles in this study in general, they did not smoke but still consumed many fatty foods. In addition, based on the length of treatment in the last 12 weeks, 244 respondents took the medication, which means that only less than half of the respondents took the pill shortly, while those who took the drug in the last 12 months were more. Judging from the access to health services, the respondents mainly chose public hospitals (community health centres) and health worker practices 159 (29.9\%) and 187 (35.2\%) for getting medical treatments. As for the payment method for medical treatment, many respondents used insurance, but few also made their payments. 


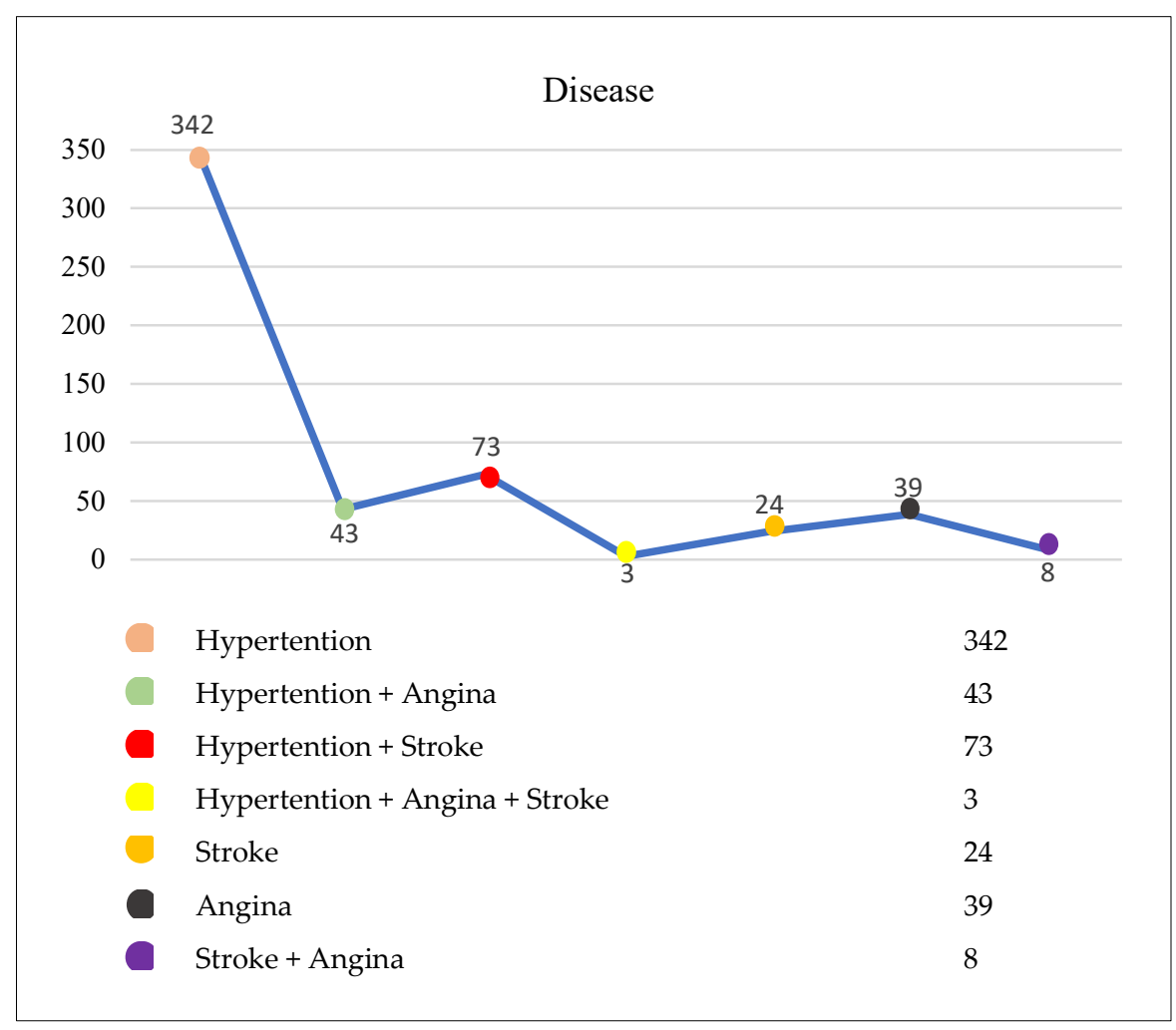

Figure 2. Patients with hypertension and its complications: clinical characteristics and complications.

Based on Figure 2, the results of the descriptive text can be seen in the distribution of respondents with hypertension and its complications. Out of 532 respondents, 342 (64.3\%) of them suffered from hypertension, indicating that hypertension affected the occurrence of other complications. Respondents with hypertension + angina were 43 (8.1\%), hypertension caused angina, hypertension + stroke were $73(13.7 \%)$, uncontrolled hypertension resulted in a high incidence of stroke, stroke were $24(4.5 \%)$, angina were $39(7.3 \%)$, stroke + angina were 8 (1.5\%). Hypertension triggered other complications. 


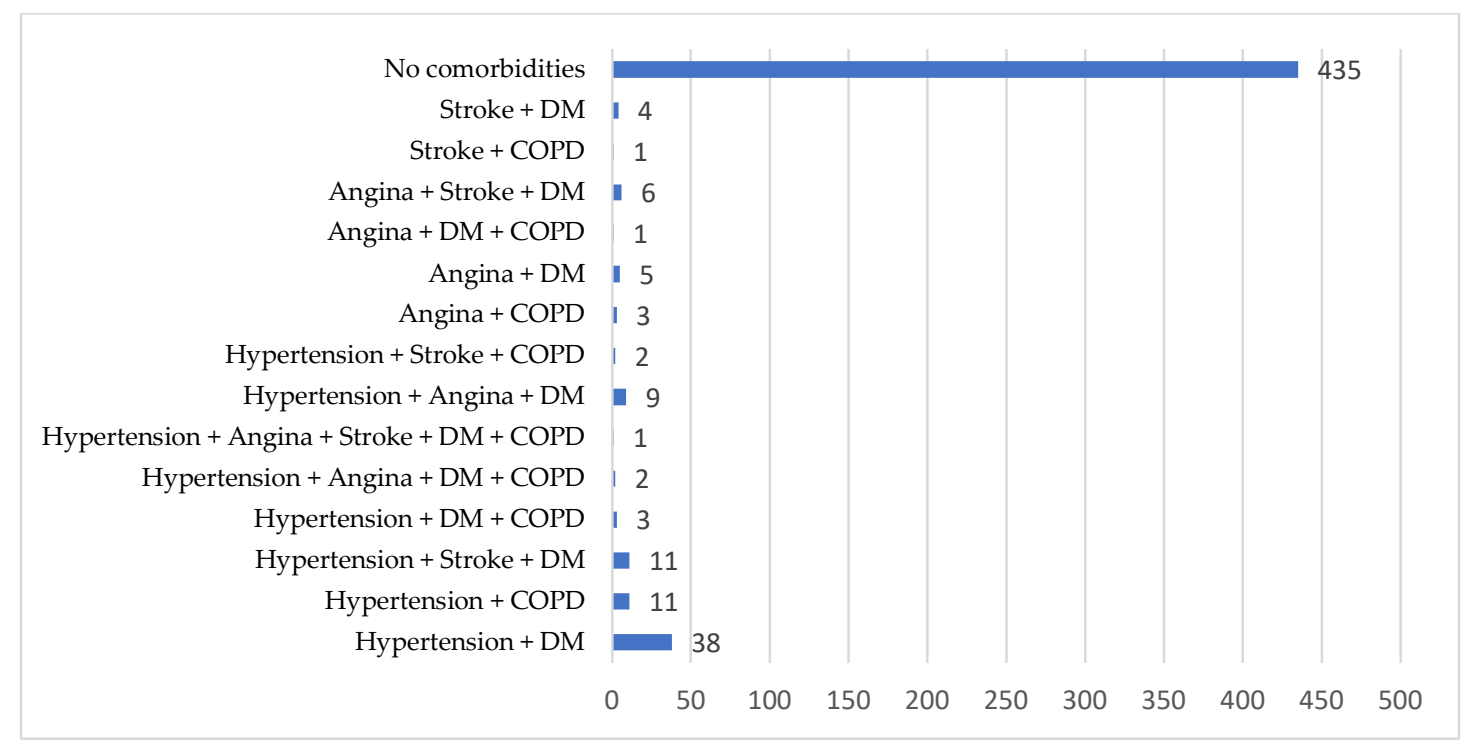

Notes: DM : Diabetes Melitus. COPD: Chronic Obstructive Pulmonary Disease

Figure 3. Patients with hypertension and its complications have a variety of comorbidities that have distinct clinical characteristics.

Based on Figure 3, it can be seen that the distribution of respondents with a history of single hypertension was more than those with hypertension and its complications (stroke and angina). More people were suffering from hypertension with stroke. When viewed from comorbidities (DM+COPD) in hypertension and its complications, hypertension with Diabetes mellitus (DM) dominated 38 respondents, but more respondents did not have comorbidities.

3.2. Relationship between Demographic Factor and The QoL of Patients with Hypertension and Its Complications 
Table 3. Relationship between demographic factor and the QoL of patients with hypertension and its complications.

\begin{tabular}{|c|c|c|c|c|c|c|c|c|}
\hline Variable & $\begin{array}{l}\text { Physical } \\
\text { Function }\end{array}$ & $\begin{array}{c}\text { Physical } \\
\text { Role }\end{array}$ & $\begin{array}{l}\text { Body } \\
\text { Aches }\end{array}$ & $\begin{array}{l}\text { General } \\
\text { health }\end{array}$ & Vitality & $\begin{array}{c}\text { Social } \\
\text { Function }\end{array}$ & $\begin{array}{c}\text { Emotional } \\
\text { Role }\end{array}$ & $\begin{array}{r}\text { Menta } \\
1 \text { Health } \\
\end{array}$ \\
\hline \multicolumn{9}{|l|}{ Gender } \\
\hline $\begin{array}{c}\text { Male } \\
\text { (average) }\end{array}$ & 254.98 & 251.36 & 257.01 & 261.28 & 276.07 & 261.55 & 269.89 & 280.51 \\
\hline $\begin{array}{l}\text { Female } \\
\text { (average) }\end{array}$ & 273.22 & 275.33 & 272.03 & 269.54 & 260.92 & 269.39 & 264.53 & 258.33 \\
\hline P-Value & 0.140 & 0.070 & 0.237 & 0.502 & 0.235 & 0.497 & 0.677 & 0.095 \\
\hline \multicolumn{9}{|l|}{ Age } \\
\hline $\begin{array}{c}<=45 \\
\text { (average) }\end{array}$ & 304.71 & 287.67 & 265.17 & 288.19 & 294.82 & 257.94 & 240.69 & 232.26 \\
\hline $\begin{array}{c}>45 \\
\text { (average) }\end{array}$ & 261.18 & 263.55 & 266.69 & 263.48 & 262.56 & 267.69 & 270.09 & 271.27 \\
\hline P-Value & $0.017^{*}$ & 0.216 & 0.935 & 0.173 & 0.086 & 0.566 & 0.120 & $0.046^{*}$ \\
\hline \multicolumn{9}{|l|}{ Education } \\
\hline $\begin{array}{c}\text { Non-University Graduate } \\
\text { (average) }\end{array}$ & 269.33 & 266.34 & 262.96 & 259.09 & 258.04 & 265.75 & 264.82 & 260.87 \\
\hline $\begin{array}{c}\text { University Graduate } \\
\text { (average) }\end{array}$ & 247.16 & 267.61 & 290.66 & 317.10 & 324.21 & 271.59 & 277.95 & 304.95 \\
\hline P-Value & 0.214 & 0.947 & 0.131 & $0.001^{*}$ & $0.000^{*}$ & 0.727 & 0.480 & $0.022^{*}$ \\
\hline \multicolumn{9}{|l|}{ Marital status } \\
\hline $\begin{array}{c}\text { Not married } \\
\text { (average) }\end{array}$ & 266.39 & 262.19 & 279.68 & 265.28 & 262.80 & 263.13 & 285.28 & 275.12 \\
\hline $\begin{array}{c}\text { Married } \\
\text { (average) }\end{array}$ & 266.54 & 268.18 & 261.37 & 266.98 & 267.94 & 267.81 & 259.19 & 263.14 \\
\hline P-Value & 0.991 & 0.674 & 0.179 & 0.898 & 0.708 & 0.706 & 0.059 & 0.401 \\
\hline \multicolumn{9}{|l|}{ Occupation } \\
\hline $\begin{array}{l}\text { Not Working } \\
\text { (average) }\end{array}$ & 269.70 & 268.01 & 265.28 & 265.21 & 247.90 & 259.54 & 253.93 & 253.93 \\
\hline $\begin{array}{l}\text { Working } \\
\text { (average) }\end{array}$ & 264.54 & 265.57 & 267.25 & 267.29 & 277.88 & 270.76 & 253.93 & 253.93 \\
\hline \multirow[t]{2}{*}{ P-Value } & 0.675 & 0.853 & 0.876 & 0.865 & $0.018^{*}$ & 0.328 & 0.113 & 0.151 \\
\hline & $\begin{array}{l}\text { Th } \\
\text { the abo } \\
\text { showed } \\
\text { with } p-\mathrm{r} \\
\text { of QoL } \\
\text { stantial } \\
\text { health ( } \\
\text { tality de }\end{array}$ & $\begin{array}{l}\text { tudy resu } \\
\text { factors } \\
\text { significan } \\
\text { ue }=0.000 \\
\text { tained a } p \\
\text { fference } i \\
\text { value }=0.0 \\
\text { ain based }\end{array}$ & $\begin{array}{l}\text { s using } t \\
\text { th eight } \\
\text { differen } \\
\text { nd ment } \\
\text { alue }<0 \text {. } \\
\text { the don } \\
\text { ) with a } \\
\text { n an occ }\end{array}$ & $\begin{array}{l}\text { Mann Whi } \\
\text { mains in } \\
n \text { the publ } \\
\text { ealth with } \\
\text { For the ch } \\
\text { of physi } \\
\text { alue }<0.05 \\
\text { ational fac }\end{array}$ & $\begin{array}{l}\text { ney test } \\
\text { oL. Jud } \\
\text { health } \\
p \text {-value } \\
\text { racterist } \\
\text { al functi } \\
\text { There } \\
\text { or, with }\end{array}$ & $\begin{array}{l}\text { alysis cou } \\
\text { ng from } \\
\text { main wit } \\
022 \text {, in w } \\
\text { of the ag } \\
\text { with } p-v \\
\text { a substa } \\
\text {-value }<0\end{array}$ & $\begin{array}{l}\text { see the rel } \\
\text { education } \\
\text {-value }=0 \text {. } \\
\text { h those thr } \\
\text { actor, there } \\
\text { ue }=0.017 \\
\text { ial differen }\end{array}$ & $\begin{array}{l}\text { ionship of } \\
\text { factor, it } \\
1 \text {, vitality } \\
\text { domains } \\
\text { vas a sub- } \\
\text { d mental } \\
\text { to the vi- }\end{array}$ \\
\hline
\end{tabular}




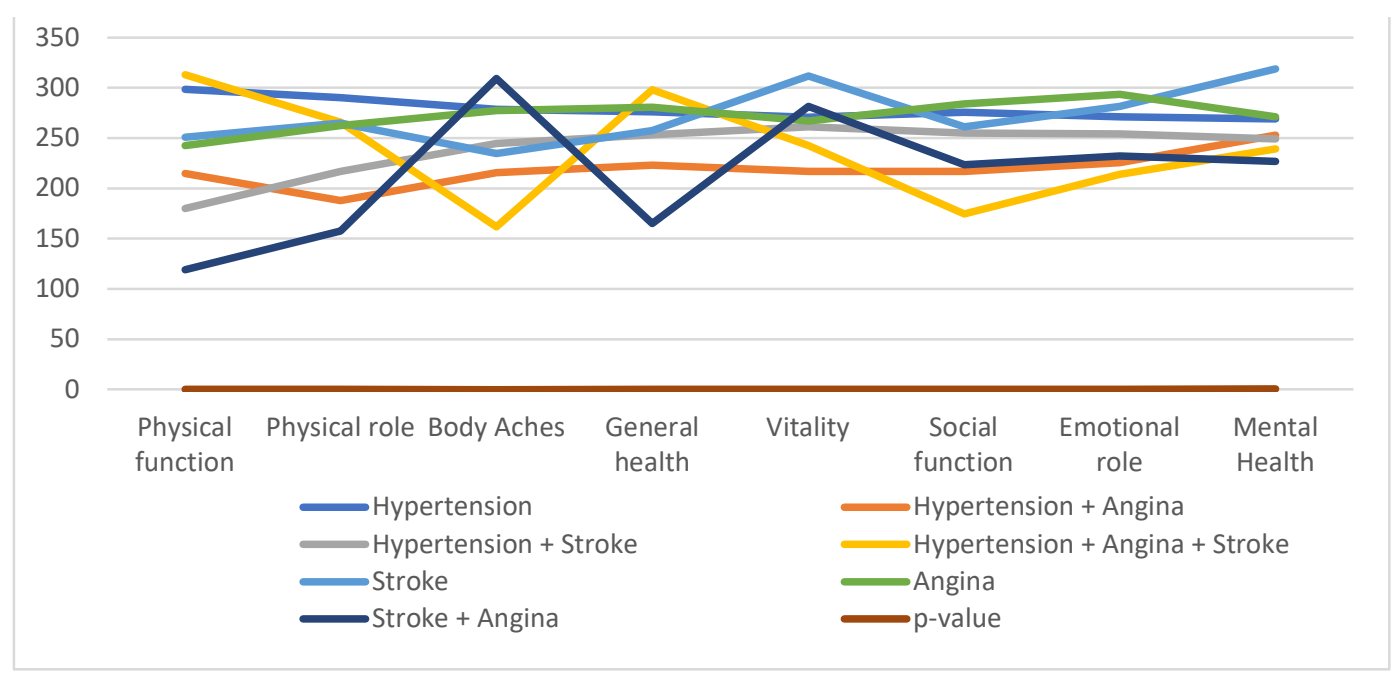

Notes: $p<0.05=$ significant difference

Figure 4. The results of bivariate analysis on the factor of hypertension and its complications to the QoL of patients with hypertension and its complications.

Based on Figure 4, the research results above showed a significant difference between physical function, physical role, body pain in patients with hypertension and its complications with a $p$-value $<0.05$, which means that these domains affected the QoL.

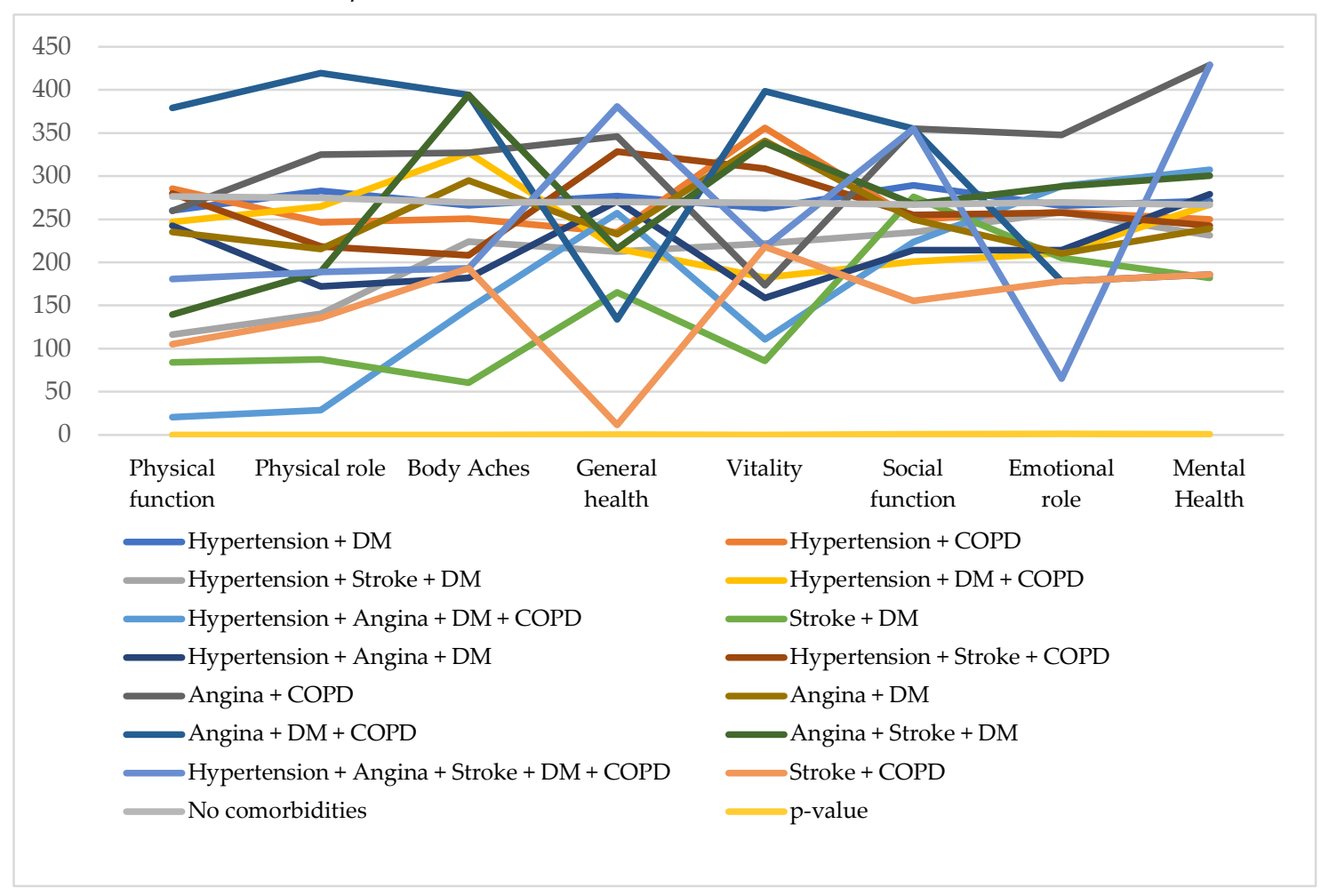

Notes: $p<0.05$ : Significant difference; DM

: Diabetes Melitus; COPD: Chronic Obstructive Pulmonary Disease

Figure 5. The results of bivariate analysis of comorbidities with QoL in patients with hypertension and its complications in Sleman Regency, Yogyakarta. 
Based on the research results on comorbidities, there were significant differences between physical function, physical role, and vitality with a $p$-value $<0.05$. It influenced the QoL in bodily function, the physical part, and energy.

\subsection{Bivariate Analysis on Lifestyle Factors of Hypertension and Its complications to The QoL}

Table 4. The results of bivariate analysis on lifestyle factors of hypertension and its complications to the QoL of patients with hypertension and its complications.

\begin{tabular}{|c|c|c|c|c|c|c|c|c|}
\hline Variable & $\begin{array}{l}\text { Physical } \\
\text { Function }\end{array}$ & $\begin{array}{c}\text { Physical } \\
\text { Role }\end{array}$ & Body Aches & $\begin{array}{l}\text { General } \\
\text { Health }\end{array}$ & Vitality & $\begin{array}{c}\text { Social } \\
\text { Function }\end{array}$ & $\begin{array}{c}\text { Emotional } \\
\text { Role }\end{array}$ & $\begin{array}{l}\text { Mental } \\
\text { Health }\end{array}$ \\
\hline \multicolumn{9}{|c|}{ Consumption of Fatty Foods } \\
\hline Everyday & 282.00 & 274.78 & 266.55 & 274.54 & 277.41 & 267.21 & 262.73 & 268.67 \\
\hline $1 x-2 x$ a week & 254.67 & 247.27 & 253.38 & 252.09 & 229.40 & 264.33 & 250.73 & 262.75 \\
\hline $3 x-6 x$ a week & 271.88 & 272.20 & 279.71 & 260.07 & 263.55 & 274.71 & 281.25 & 247.56 \\
\hline$<3 x$ a month & 234.62 & 261.44 & 271.74 & 264.87 & 279.29 & 261.55 & 283.68 & 277.19 \\
\hline$P$ & 0.864 & 0.871 & 0.703 & 0.993 & 0.299 & 0.492 & 0.973 & 0.081 \\
\hline \multicolumn{9}{|c|}{ Smoking } \\
\hline $\begin{array}{c}\text { No } \\
\text { Average }\end{array}$ & 266.54 & 267.89 & 268.53 & 265.91 & 266.86 & 264.36 & 266.91 & 264.77 \\
\hline $\begin{array}{c}\text { Yes } \\
\text { Average }\end{array}$ & 266.13 & 254.95 & 249.55 & 271.44 & 263.50 & 284.35 & 263.10 & 280.94 \\
\hline$P$ & 0.983 & 0.530 & 0338 & 0773 & 0.866 & 0.267 & 0.849 & 0.435 \\
\hline
\end{tabular}
Notes: $p<0.05=$ significant difference.

Based on the research results in the table above, it showed no significant difference between the eight domains of QoL to the consumption of fatty foods and smoking for one month in patients with hypertension and its complications with a value of $p$-value $>0.05$.

3.4. Bivariate Analysis on The Factor of Length-of-Time in Taking Drugs for Hypertension and Its Complications to The QoL

Table 5. The results of bivariate analysis on the factor of length-of-time in taking drugs for hypertension and its complications to the QoL of patients with hypertension and its complications.

\begin{tabular}{|c|c|c|c|c|c|c|c|c|}
\hline Variable & $\begin{array}{l}\text { Physical } \\
\text { Function }\end{array}$ & $\begin{array}{c}\text { Physical } \\
\text { Role }\end{array}$ & $\begin{array}{c}\text { Body } \\
\text { Aches }\end{array}$ & $\begin{array}{c}\text { General } \\
\text { Health }\end{array}$ & Vitality & $\begin{array}{c}\text { Social } \\
\text { Function }\end{array}$ & $\begin{array}{c}\text { Emotional } \\
\text { Role }\end{array}$ & $\begin{array}{l}\text { Mental } \\
\text { Health }\end{array}$ \\
\hline \multicolumn{9}{|c|}{ The Last 2 Weeks } \\
\hline No (average) & 287.33 & 282.72 & 273.74 & 273.31 & 274.06 & 269.19 & 268.95 & 270.52 \\
\hline Yes (average) & 241.92 & 247.35 & 257.95 & 258.46 & 257.58 & 263.32 & 263.61 & 261.75 \\
\hline P-Value & $0.000^{*}$ & $0.006^{*}$ & 0.199 & 0.213 & 0.183 & 0.600 & 0.668 & 0.495 \\
\hline \multicolumn{9}{|c|}{ The Last 12 Months } \\
\hline No (average) & 278.51 & 278.32 & 268.52 & 272.93 & 280.64 & 270.51 & 267.05 & 254.85 \\
\hline Yes (average) & 259.88 & 259.99 & 265.39 & 262.96 & 258.71 & 264.29 & 266.20 & 272.92 \\
\hline P-Value & 0.135 & 0.169 & 0.807 & 0.422 & 0.088 & 0.593 & 0.947 & 0.177 \\
\hline
\end{tabular}

Based on the results of the research in the table above, there was a significant difference between the physical function domain with $p$-value $=0.000$ and the physical role domain with $p$-value $=0.006$ in taking the drugs in the last two weeks with a $p$-value $<0.05$, which means that taking the drugs in the previous two weeks affected the QoL in the domains of physical function and physical role.

\subsection{Bivariate Analysis on The Access to Health Services on The QoL of Patients with Hypertension and Its Complications}

Table 6. The results of bivariate analysis on the access to health services on the QoL of patients with hypertension and its complications. 


\begin{tabular}{ccccccccc}
\hline Variable & $\begin{array}{c}\text { Physical } \\
\text { Function }\end{array}$ & $\begin{array}{c}\text { Physical } \\
\text { Role }\end{array}$ & Body Aches & $\begin{array}{c}\text { General } \\
\text { Health }\end{array}$ & Vitality & $\begin{array}{c}\text { Social } \\
\text { Function }\end{array}$ & $\begin{array}{c}\text { Emotional } \\
\text { Role }\end{array}$ & $\begin{array}{c}\text { Mental } \\
\text { Health }\end{array}$ \\
\hline Public & & & \multicolumn{2}{c}{ Place for Medical Treatment } \\
$\begin{array}{c}\text { Hospital/Puskesmas } \\
\text { Private Hospital }\end{array}$ & 265.93 & 272.20 & 262.38 & 253.11 & 245.82 & 265.17 & 266.58 & 269.38 \\
Health Worker & 218.87 & 232.86 & 256.98 & 264.96 & 253.63 & 271.48 & 255.70 & 239.21 \\
$\quad$ Practices & 280.86 & 278.11 & 266.28 & 268.91 & 280.14 & 271.77 & 271.99 & 268.53 \\
Others & 283.45 & 265.65 & 282.42 & 285.23 & 285.90 & 253.94 & 265.69 & 282.90 \\
P-Value & $0.003^{*}$ & 0.109 & 0.621 & 0.335 & 0.054 & 0.707 & 0.853 & 0.228 \\
\hline Smoking & & & & & & & & \\
Insurance & 255.88 & 264.81 & 264.32 & 257.37 & 262.11 & 263.22 & 270.42 & 266.96 \\
Independently & 271.11 & 267.18 & 258.21 & 267.01 & 261.44 & 275.91 & 260.96 & 257.58 \\
No treatment & 285.48 & 269.64 & 290.96 & 290.51 & 289.84 & 254.60 & 268.03 & 285.10 \\
P-Value & 0.185 & 0.962 & 0.182 & 0.148 & 0.236 & 0.371 & 0.782 \\
\hline
\end{tabular}

Notes: $p<0.05=$ significant difference.

In table 6, the results showed a significant difference between the place for medical treatment and the physical function domain with $p$-value $=0.003$ or $p$-value $<0.05$, which means that the place for medical treatment affected the QoL in the environment of physical function.

3.6. Multivariate Analysis on the Factors of Demography, Comorbidity, Lifestyle, Medication and Access to Health Services to the Physical and Mental Health Components

Table 7. The Results of Multivariate Analysis on the Factors of Demography, Comorbidity, Lifestyle, Medication and Access to Health Services to the Physical and Mental Health Components.

\begin{tabular}{|c|c|c|c|c|}
\hline \multicolumn{5}{|c|}{ Domain Group SF 12 (Angina) } \\
\hline Variable & $\begin{array}{c}\text { Physical Health } \\
\text { Component }\end{array}$ & P-Value & $\begin{array}{c}\text { Mental Health } \\
\text { Component }\end{array}$ & P-Value \\
\hline \multicolumn{5}{|l|}{ Gender } \\
\hline Male & 244.35 & \multirow{2}{*}{$0.011^{*}$} & 283.30 & \multirow{2}{*}{0.054} \\
\hline Female & 279.72 & & 256.70 & \\
\hline \multicolumn{5}{|l|}{ Age } \\
\hline$\leq 45$ years old & 315.18 & \multirow{2}{*}{$0.006^{*}$} & 232.87 & \multirow{2}{*}{0.060} \\
\hline$>45$ years old & 359.72 & & 271.18 & \\
\hline \multicolumn{5}{|l|}{ Marital Status } \\
\hline Not Married & 261.65 & \multirow{2}{*}{0.650} & 277.34 & \multirow{2}{*}{0.310} \\
\hline Married & 268.39 & & 262.28 & \\
\hline \multicolumn{5}{|l|}{ Education } \\
\hline Non-University Graduate & 265.12 & \multirow{2}{*}{0.588} & 259.07 & \multirow{2}{*}{$0.004^{*}$} \\
\hline University Graduate & 275.93 & & 317.71 & \\
\hline \multicolumn{5}{|l|}{ Occupation } \\
\hline Not Working & 273.64 & \multirow{2}{*}{0.402} & 243.17 & \multirow{2}{*}{$0.006^{*}$} \\
\hline Working & 262.13 & & 280.78 & \\
\hline \multicolumn{5}{|l|}{ Hypertension and its complications } \\
\hline Hypertension & 299.67 & \multirow{7}{*}{$0.000^{*}$} & 262.89 & \multirow{7}{*}{0.364} \\
\hline Hypertension+angina & 181.26 & & 241.23 & \\
\hline Hypertension+stroke & 192.15 & & 270.18 & \\
\hline Hypertension +angina+stroke & 327.00 & & 166.33 & \\
\hline Stroke & 239.08 & & 318.08 & \\
\hline Angina & 244.44 & & 292.85 & \\
\hline Stroke+angina & 152.38 & & 277.63 & \\
\hline \multicolumn{5}{|l|}{ Comorbidities } \\
\hline Hypertension+DM & 261.67 & \multirow{2}{*}{$0.002^{*}$} & 272.62 & \multirow{2}{*}{0.847} \\
\hline Hypertension+COPD & 264.36 & & 285.18 & \\
\hline
\end{tabular}




\begin{tabular}{|c|c|c|c|c|}
\hline Hypertension+stroke+DM & 129.59 & & 267.59 & \\
\hline Hypertension+DM+COPD & 270.67 & & 211.67 & \\
\hline Hypertension+angina+DM+COPD & 16.50 & & 442.00 & \\
\hline Stroke+DM & 44.13 & & 227.00 & \\
\hline Hypertension+angina+DM & 174.17 & & 215.67 & \\
\hline Hypertension+stroke+COPD & 168.00 & & 274.75 & \\
\hline Angina $+\mathrm{COPD}$ & 267.33 & & 385.17 & \\
\hline Angina+DM & 244.60 & & 257.60 & \\
\hline Angina+DM+COPD & 463.50 & & 200.50 & \\
\hline Angina+stroke+DM & 188.33 & & 359.67 & \\
\hline No comorbidities & 277.36 & & 264.63 & \\
\hline Hypertension+angina+stroke+DM+COPD & 223.00 & & 261.00 & \\
\hline Stroke+COPD & 83.00 & & 243.50 & \\
\hline Fatty Foods & & & & \\
\hline Everyday & 282.21 & \multirow{4}{*}{$0.048^{*}$} & 262.22 & \multirow{4}{*}{0.360} \\
\hline $1-2 x /$ week & 245.45 & & 254.78 & \\
\hline $3-4 x /$ week & 277.22 & & 266.48 & \\
\hline$<3 x /$ month & 240.43 & & 290.39 & \\
\hline \multicolumn{5}{|l|}{ Smoking } \\
\hline No & 268.99 & \multirow{2}{*}{0.281} & 264.50 & \multirow{2}{*}{0.387} \\
\hline Yes & 245.78 & & 283.13 & \\
\hline \multicolumn{5}{|l|}{ Drug Consumption in the Last 2 Weeks } \\
\hline Not Consuming & 287.63 & \multirow{2}{*}{$0.001^{*}$} & 263.28 & \multirow{2}{*}{0.599} \\
\hline Consuming & 241.56 & & 270.31 & \\
\hline \multicolumn{5}{|l|}{ Drug Consumption in the Last 12 Months } \\
\hline Not Consuming & 282.73 & \multirow{2}{*}{0.071} & 262.02 & \multirow{2}{*}{0.617} \\
\hline Consuming & 257.56 & & 268.97 & \\
\hline \multicolumn{5}{|l|}{ Place for Medical Treatment } \\
\hline Public Hospital/puskesmas & 258.77 & \multirow{4}{*}{0.053} & 260.07 & \multirow{4}{*}{0.886} \\
\hline Private Hospital & 232.34 & & 262.43 & \\
\hline Health Worker Practices & 278.93 & & 272.31 & \\
\hline No Treatment and others & 286.54 & & 269.58 & \\
\hline \multicolumn{5}{|l|}{ Payment Method } \\
\hline Insurance & 253.84 & \multirow{3}{*}{0.087} & 270.87 & \multirow{3}{*}{0.682} \\
\hline Independently & 269.15 & & 258.93 & \\
\hline No treatment & 295.46 & & 271.33 & \\
\hline
\end{tabular}

Notes: $p<0.05$ = significant differences; DM: Diabetes Mellitus; COPD: Chronic Obstructive Pulmonary Disease.

Based on Table 7, the results showed that the factors related to physical components were the variable of gender with $p$-value $=0.011$, age with $p$-value $=0.006$, diagnosis of hypertension and its complications with $p$-value $=0.000$, comorbidities with $p$-value $=0.002$, consumption of fatty foods with $p$-value $=0.048$ and medical treatment in the last two weeks with $p$-value $=0.001$. Meanwhile, the factors related to the mental component were the variable of occupation with $p=0.006$ and education with $p=0.004$, which were seen from the $p$-value $<0.05$.

\section{Discussion}

\subsection{Bivariate analysis on the relationship of factors to 8 domains of $Q o L$}

Based on the bivariate analysis results, there was no significant difference between gender to the eight domains of QoL. Based on the analysis [18], there was a relationship between the gender of individuals who suffered from hypertension and the level of hypertension with a $p$-value $=0.522$.

Based on the age factor showed a significant difference in physical function and mental health. There's a connection between the incidence of hypertension and age with a pvalue of 0.00 in bivariate analysis [19]. Therefore, age is a non-modifiable risk factor for hypertension. Various factors can cause hypertension, one of which is increasing age, 
making the physiology of a person's body change, for example, artery walls that thicken due to collagen substances accumulate in the muscle layer, causing vasoconstriction stiff blood vessels [20], [21].

According to the bivariate analysis on educational factors, there were significant differences in general health, vitality and mental health. The results obtained from the study showed that there was a significant relationship between education and patients with hypertension. Relations between education and hypertension levels got a value of $p$-value [22]. The average incidence of hypertension is high in those with low educational experience. The level of someone's education can support or influence that individual. Extensive knowledge goes hand in hand with high educational background and vice versa. When the academic environment is low, then the ability is also narrow. Toward the relationship between the level of education and the incident of hypertension with p-value 0.042 [23].

bivariate analysis on the marital status factor showed that the eight domains of QoL did not affect patients' marital status with hypertension and its complications. However, if seen from the average value of unmarried status, the values were low for physical function, physical role and social position. These results are comparable to previous studies, where the comparison between people who are on good terms with family and those who have a bad relationship with family has low scores in physical function, physical role and emotional role [24]. But if seen from the average score in the domains of physical function and physical position, those who had married status were higher than those who were not married. Patients who live with a partner have a much better QoL than those who live alone. This is because the family can support their life where they won't feel lonely. After all, someone is talking to them. It also makes it easier to ask for help [25], [26].

Based on the bivariate analysis on the occupation factor, there was a significant difference in the vitality domain. The employment variable has to do with the incident of hypertension with $\mathrm{p}$-value 0.001 . This shows that there were more hypertensive patients among those who did not work than those who worked, and the results of calculation on the prevalence ratio indicated that patients who did not work were 1.830 times more likely to develop hypertension than those who worked. In the research, work is related to the QoL because if it is seen from the background of research respondents, more respondents did not work. Therefore, insufficient physical activity is possible as a cause of hypertension [27].

The bivariate analysis above showed significant differences between the domains of physical function, physical role, and body aches in patients with hypertension and its complications. Continuously high blood pressure can damage the endothelium, which can accelerate the occurrence of atherosclerosis. Cerebrovascular disease such as stroke can be caused by high blood pressure. In addition, it causes coronary artery diseases such as angina and myocardial infarction. The impact of hypertension will be more if a person has cardiovascular disease. It can increase mortality and morbidity rates in hypertensive patients [28], [29].

Based on bivariate analysis of comorbidities, it showed an influence on the QoL in the domains of physical function, physical role, body aches and vitality. The decreased QoL in the physical domain occurs due to hypertensive patients' lack of physical activity, especially for heart problems. They tend to think that physical activity will worsen their body condition and cause fatigue or even a recurrence of their illness. Comorbidities such as heart problems in hypertensive patients had a good score above 60 in the emotional and mental health domains. Meanwhile, the scores below 60 were in the physical environments that were not good enough. Whereas hypertensive patients with DM comorbidities were seen from 8 dimensions measured for QoL, in the general health dimension, the score showed a value below 60, while in other sizes, it showed a score above 60 [30].

Taking the medication in the last two weeks affected the QoL in physical function and physical role. Adherence in taking medication makes people with hypertension get better. Relationship between medication adherence and QoL with a $p$-value $=0.000 \mathrm{ob}$ tained from the linear regression statistical test. Patients who take medication on time and routinely have a better physique can affect their QoL. Adherence to taking the medication 
regularly affects the body's physical activity, which causes the long duration of hypertension. Knowing the factors of QoL early can improve physical and mental health [31].

As for the length of treatment in the last 12 months, there was no significant difference between the eight domains to drug consumption in the previous 12 months, which means that the lifestyle of taking the medication in the last 12 months did not affect the QoL of patients with hypertension and its complications. Time of treatment and blood pressure control had a significant effect on HRQoL. Likewise, the number of antihypertensive drugs consumed by patients and the number of doses/day did not affect the HRQoL. Regarding the type of treatment, it is unlikely to affect HRQoL because of the wide variety of combinations [32]. This is consistent with this study in which the treatment did not affect the QoL in any domain. However, this study lacks questions about the specification of drugs consumed by the patients.

The place for medical treatment affected the QoL in the domain of physical function. A person who goes to the area for treatment can check the disease to prevent it from recurring. This can affect the QoL of the patients. The most visited place for hypertensive patients was community health centres [33]. Bivariate analysis showed a significant relationship between Puskesmas visits to the motivation of hypertensive patients with $p$-value $=0,000$, which means that treatment at Puskesmas affected the QoL of patients with hypertension and its complications. Regular Puskesmas visits are to control the patient's blood pressure, so this is very important. The length of time needed and long distance to the place for treatment make hypertensive patients choose the nearest health service places or even become the reason for the patients not to go for treatment.

Based on the bivariate analysis on the payment method, there was no significant difference in the eight domains with a value of $p$-value $>0.05$, which means that the payment method did not affect the QoL in the eight domains. The process of payment does not affect the QoL [34]. Patients with hypertension mostly use JKN PBI insurance. Hypertensive patients with JKN PBI status do not pay for inpatient care. JKN PBI insurance is beneficial in implementing health services to achieve better therapy for people with hypertension. This is evidenced by the high health rates using such insurance. With this insurance, someone with a low economy can continue their treatment.

\subsection{Multivariate analysis of the relationship between the factors on the components of physical and mental health}

Based on the distribution of the characteristics of the sex of the respondents, it was seen that the most were women. Many women suffer from hypertension because hormones in women cause it. Women experience menopause which will increase the risk of high blood pressure, the presence of estrogen in women has the function to increase HDL (High-Density Lipoprotein), but in postmenopausal women, the production of this hormone will decrease. Low HDL cholesterol levels and high LDL cholesterol lead to atherosclerosis, which increases blood pressure [35], [36].

Age affects the summary of physical components. Generally, hypertension occurs in someone over 40 years of age. A person who is more than 40 years old allows one of the physiological changes, such as the condition of the walls of the blood vessels, to lose their elasticity. Without the dilation of blood vessels and the continuous pumping of blood causing an increase in blood pressure. If they occur continuously, such conditions can affect the QoL, especially in physical activity [37].

Hypertension and its complications (stroke and angina) and comorbidities (DM and COPD) affect the summary of the physical components. This result is not following previous research by Saxena and Mendenhall (2020), where the comorbidity, $p=0.045$, showed a significant relationship with the MCS scores, not the PCS scores [38]. The results obtained are also comparable to previous research by Dumitra et al. (2019), where the complication factor did not show a significant relationship to the PCS scores but was substantial on the MCS scores where the $p$-value $=0.001$ the results obtained were following this study which significantly affected the MCS scores [39]. Worse QoL was statistically 
significant in all domains among patients diagnosed with hypertension with stroke than among those with hypertension alone. The presence of other chronic diseases, limiting one's physical activity, making more drugs, and more drug side effects consumed and experienced by patients can affect the patient's QoL and patient compliance. Symptoms of hypertension and cardiovascular diseases or other diseases at the same time will significantly impact the QoL of a person in various aspects, especially on the patient's physical health.

Comorbidities (DM and COPD) affect the summary of the physical components. Various factors contribute to the incidence of hypertension, and one of them is DM, where the type $2 \mathrm{DM}$ patients with obesity often experience hypertension. This happens because hypertension can cause cell insensitivity to insulin. This insulin functions in regulating carbohydrate metabolism by increasing glucose uptake in cells to disturb blood sugar levels.

The consumption of fatty foods affects the summary of the physical components. Consumption of rich foods includes the risk factors for hypertension that can be controlled, namely lifestyle and behaviour such as lack of activity, obesity, food consumption and stress. In fatty foods, there are cholesterol and saturated fats. High-fat levels in the blood can cause blood vessel blockage to affect or interfere with the cardiovascular system. Fat can indirectly lead to hypertension which can lead to cardiovascular diseases. So that if a patient with hypertension experiences complications of strokes and heart attacks, it will be able to reduce the QoL of the sufferer, which can be due to more symptoms that arise, and the consequences of the illness can facilitate socialization with the environment, as well as mental health.

Medical treatment in the last two weeks affects the summary of the physical components. Dedication to taking medication routinely affects the body's physical activity, which causes the duration of hypertension. So that the higher the patient's compliance, the greater the decrease and control of their blood pressure, which can improve his QoL [40].

Educational factors influence the mental component summary. Hypertensive patients with a low level of education have a worse condition with lower physical function scores and body ache than those with higher education. This study has more influence on the physical component of hypertensive patients than the mental component, but in this study, education has more impact on the summary of the mental element. This may be due to different social life and expectations [41].

Occupational factor influences the mental component summary. This is not following Xu et al., (2016) research, which found that among those who suffered from hypertension were unemployed people who had better general health and had poor social function than those who work, which means that the research affects the summary mental components. However, this is consistent with this study, where the overview of mental details affects both working and non-working people. This is because those who do not work have low socioeconomic status, resulting in a poor QoL [42].

\section{Conclusions}

The results obtained in this study were the QoL of patients with hypertension and its complications, in which several factors such as gender $(p=0.011)$, age $(p=0.006)$, diagnosis of hypertension and its complications $(p=0.000)$, the presence of comorbidities $(p=0.002)$, fatty foods $(p=0.048)$, drug consumption in the last two weeks $(p=0.001)$ were related to the QoL of patients with hypertension and its complications on the physical component (PCS), while the factors related to the mental component (MCS) were education $(p=0.004)$ and occupation $(p=0.006)$. Gender and age affect hormonal, physiological and functional changes in the body and perceptions between each individual that affect their QoL. Furthermore, lifestyle such as consuming fatty foods and drugs in the last two weeks can affect blood vessels and blood pressure control, affecting the QoL of people with hypertension and its complications. Meanwhile, factors related to the mental component (MCS) were education $(p=0.004)$ and occupation $(p=0.006)$. These factors may be related to the 
patient's low social life and socioeconomic status and affect the QoL, especially in the mental aspect.

Self-awareness is needed for patients with hypertension and its complications regarding unhealthy lifestyle factors that lead to hypertension. Lack of knowledge and lack of education are among the factors that need to be considered to improve the QoL.

Acknowledgments: The researchers would like to thank all those who have assisted in achieving this journal until its publication. Researcher's parents, relatives, supervisors, discussants, and friends who were very helpful to researchers who cannot be named one by one. This paper uses data from Sleman HDSS (Health and Demographic Surveillance System) wave 2,3 version HDSS_ALLSIKLUS_rel9-1-2. The Sleman HDSS data collection has been primarily funded by Faculty of Medicine, Public Health, and Nursing, Universitas Gadjah Mada, Yogyakarta, Indonesia.

Funding: This study is collaboration research with used data from Sleman HDSS. Sleman HDSS is fully funded and conducted by Faculty of Medicine, Public Health and Nursing (FKKMK), UGM. Thus, Sleman HDSS data use follows the terms and conditions implemented by FKKMK UGM. During the first 2 years after data collection, data is only accessible for Sleman HDSS' researchers and academics community in FKKMK UGM. Afterwards, broader academic communities (e.g., from other universities) are welcome to use Sleman HDSS data. The terms and conditions of Sleman HDSS data use require every user to send the data use application form and brief proposal to Sleman HDSS office for review and to apply for ethical clearance from UGM Medical and Health Research Ethics Committee (MHREC). The applicant will receive the dataset after Sleman HDSS' reviewers and MHREC approve their application. The data set provided by Sleman HDSS does not include any information that can be used to identify the respondents. Furthermore, the data use terms and conditions also prohibit the data user to make any attempts to identify the respondents. This publication was supported by International Publication and Collaborative Center (IPCC) and Department of Pharmacy, Faculty of Mathematics and Natural Sciences, Tadulako University, Indonesia.

Institutional Review Board Statement: The study was approved by the Medical and Health Research Ethics Committee Faculty of Medicine, Public Health and Nursing, Gadjah Mada University, with reference number: KE/FK/1253/EC/ 2020.

Data Availability Statement: The main purpose of the "restriction" in Sleman HDSS data use is to protect Sleman HDSS' respondent personal information. In addition, it also prevents the data use for commercial purposes and prevents duplication in publications based on Sleman HDSS data. Further questions regarding the research ethics of Sleman HDSS data use can be directed to the UGM Medical and Health Research Ethics Committee (mhrec_fmugm@ugm.ac.id ; 0274588688 extension $17225,+62811-2666-869$ ). Detailed information regarding the procedure of data use and application for data use is available in https://hdss.fk.ugm.ac.id/. Further questions can be sent to hdssjogja.fkkmk@ugm.ac.id.

Conflicts of Interest: The authors declare no conflict of interest.

\section{References}

1 X. Gai et al., "Echinacoside prevents hypoxic pulmonary hypertension by regulating the pulmonary artery function," Journal of Pharmacological Sciences, vol. 144, no. 4, pp. 237-244, Dec. 2020, doi: 10.1016/j.jphs.2020.09.002.

2 Agnieszka Skowron, Sebastian Polak, and Jerzy Brandys, "The impact of pharmaceutical care on patients with hypertension and their pharmacists," Pharm Pract (Granada), vol. 9, no. 2, Jun. 2011, Accessed: Jun. 08, 2021. [Online]. Available: https://pharmacypractice.org/journal/index.php/pp/article/view/78

3 Anna Ivanova, Dragana Lakic, Vesna Andric, and Guenka Petrova, "Cost of outpatient hypertension pharmacotherapy - comparative study between Bulgaria and Serbia," Pharm Pract (Granada), vol. 7, no. 2, Jun. 2009, Accessed: Jun. 08, 2021. [Online]. Available: https://pharmacypractice.org/journal/index.php/pp/article/view/168

4 D. Jefic, "Low prevelence of primary aldosteronism in hypertensive diabetics," American Journal of Hypertension, vol. 17, no. 5, p. S237, May 2004, doi: 10.1016/j.amjhyper.2004.03.634.

5 Ismail A. Suleiman, Ebubechukwu O. Amogu, and Kehinde A. Ganiyu, "Prevalence and control of hypertension in a Niger Delta semi urban community, Nigeria," Pharm Pract (Granada), vol. 11, no. 1, Mar. 2013, Accessed: Jun. 08, 2021. [Online]. Available: https://pharmacypractice.org/journal/index.php/pp/article/view/176

6 E. B. Rosenzweig and U. Krishnan, "Congenital Heart Disease-Associated Pulmonary Hypertension," Clinics in Chest Medicine, vol. 42, no. 1, pp. 9-18, Mar. 2021, doi: 10.1016/j.ccm.2020.11.005.

7 A. S. Go et al., "Heart Disease and Stroke Statistics-2013 Update: A Report From the American Heart Association," Circulation, vol. 127, no. 1, Jan. 2013, doi: 10.1161/CIR.0b013e31828124ad. 
8 A. M. Daugherty, "Hypertension-related risk for dementia: A summary review with future directions," Seminars in Cell $\mathcal{E}$ Developmental Biology, p. S1084952121000343, Mar. 2021, doi: 10.1016/j.semcdb.2021.03.002.

9 V. Dilsizian et al., "Cardiac Imaging for Coronary Heart Disease Risk Stratification in Chronic Kidney Disease," JACC: Cardiovascular Imaging, vol. 14, no. 3, pp. 669-682, Mar. 2021, doi: 10.1016/j.jcmg.2020.05.035.

10 S. H. Lee et al., "Comprehensive assessment of heart failure in patients with preserved ejection fraction undergoing coronary bypass grafting," The Journal of Thoracic and Cardiovascular Surgery, p. S0022522321009806, Jun. 2021, doi: 10.1016/j.jtcvs.2021.06.026.

$11 \mathrm{M}$. H. Olsen et al., "A call to action and a lifecourse strategy to address the global burden of raised blood pressure on current and future generations: the Lancet Commission on hypertension," The Lancet, vol. 388, no. 10060, pp. 2665-2712, Nov. 2016, doi: 10.1016/S0140-6736(16)31134-5.

12 L. Raveendran et al., "Integrative review and evaluation of QoL related instruments in pediatric urology," Journal of Pediatric Urology, p. S1477513121001273, Mar. 2021, doi: 10.1016/j.jpurol.2021.03.011.

13 A. Presciutti, J. A. Shaffer, M. Newman, and S. M. Perman, “Modifiable provider-patient relationship factors and illness perceptions are associated with QoL in survivors of cardiac arrest with good neurologic recovery," Resuscitation Plus, vol. 3, p. 100008, Sep. 2020, doi: 10.1016/j.resplu.2020.100008.

14 E. T. T. Go and W. Goggins, "Comparison of the glycemic control of the normo- and hypertensive Chinese patients with type 2 diabetes in a general outpatient clinic in Hong Kong," Diabetes \& Metabolic Syndrome: Clinical Research E Reviews, vol. 3, no. 1, pp. 2934, Jan. 2009, doi: 10.1016/j.dsx.2008.10.012.

15 E. R. de Arruda Junior et al., "Risk factors related to hypertension among patients in a cohort living with HIV/AIDS," The Brazilian Journal of Infectious Diseases, vol. 14, no. 3, pp. 281-287, May 2010, doi: 10.1016/S1413-8670(10)70057-X.

16 L. G. Ngwira et al., "A Systematic Literature Review of Preference-Based Health-Related Quality-of-Life Measures Applied and Validated for Use in Childhood and Adolescent Populations in Sub-Saharan Africa," Value in Health Regional Issues, vol. 25, pp. 3747, Sep. 2021, doi: 10.1016/j.vhri.2020.11.009.

17 M. E. Hilliard et al., "Design and psychometrics for new measures of health-related QoL in adults with type 1 diabetes: Type 1 Diabetes and Life (T1DAL)," Diabetes Research and Clinical Practice, vol. 174, p. 108537, Apr. 2021, doi: 10.1016/j.diabres.2020.108537.

18 E. Martinez-Ríos, L. Montesinos, M. Alfaro-Ponce, and L. Pecchia, "A review of machine learning in hypertension detection and blood pressure estimation based on clinical and physiological data," Biomedical Signal Processing and Control, vol. 68, p. 102813, Jul. 2021, doi: 10.1016/j.bspc.2021.102813.

19 N. Widjaya, F. Anwar, R. Laura Sabrina, R. Rizki Puspadewi, and E. Wijayanti, “Hubungan Usia Dengan Kejadian Hipertensi di Kecamatan Kresek dan Tegal Angus, Kabupaten Tangerang," j.kedokt.YARSI, vol. 26, no. 3, p. 131, Feb. 2019, doi: 10.33476/jky.v26i3.756.

20 Y. Fan, D. He, S. Liu, Y. Qiao, H. Gao, and L. Xin, “Association between visceral adipose index and risk of hypertension in a middleaged and elderly Chinese population," Nutrition, Metabolism and Cardiovascular Diseases, p. S0939475321002179, May 2021, doi: 10.1016/j.numecd.2021.04.024.

21 Y. Gu et al., "Handgrip strength as a predictor of incident hypertension in the middle-aged and older population: The TCLSIH cohort study," Maturitas, vol. 150, pp. 7-13, Aug. 2021, doi: 10.1016/j.maturitas.2021.06.002.

22 A. Sutriyawan, R. Apriyani, and T. G. Miranda, "The Relationship between Lifestyle and Hypertension Cases at UPT Cibiru Public Health Center Bandung City," Dis. Prevention and Public Health J., vol. 15, no. 1, p. 50, Apr. 2021, doi: 10.12928/dpphj.v15i1.2456.

23 J. S. Coelho et al., "Alcoholic beverage consumption, changes in blood pressure and incidence of hypertension in the Longitudinal Adult Health Study (ELSA-Brasil)," Nutrition, p. 111387, Jun. 2021, doi: 10.1016/j.nut.2021.111387.

24 M. Xiao, F. Zhang, N. Xiao, X. Bu, X. Tang, and Q. Long, "Health-Related QoL of Hypertension Patients: A Population-Based CrossSectional Study in Chongqing, China," IJERPH, vol. 16, no. 13, p. 2348, Jul. 2019, doi: 10.3390/ijerph16132348.

25 K. Kalantar-Zadeh et al., "Living well with kidney disease by patient and care-partner empowerment: Kidney health for everyone everywhere," Nefrología (English Edition), vol. 41, no. 2, pp. 95-101, Mar. 2021, doi: 10.1016/j.nefroe.2021.05.002.

26 B. Moellenbeck, F. Horst, G. Gosheger, C. Theil, L. Seeber, and T. Kalisch, "Does Total Hip or Knee Arthroplasty Have an Effect on the Patients' Functional or Behavioral Outcome and Health-Related QoL of the Affected Partners?," The Journal of Arthroplasty, vol. 36, no. 3, pp. 885-891, Mar. 2021, doi: 10.1016/j.arth.2020.08.066.

27 F. Maulidina, “Faktor-Faktor yang Berhubungan dengan Kejadian Hipertensi di Wilayah Kerja Puskesmas Jati Luhur Bekasi Tahun 2018," arkesmas, vol. 4, no. 1, pp. 149-155, Jun. 2019, doi: 10.22236/arkesmas.v4i1.3141.

28 Y.-X. Wang et al., "Hypertensive Disorders of Pregnancy and Subsequent Risk of Premature Mortality," Journal of the American College of Cardiology, vol. 77, no. 10, pp. 1302-1312, Mar. 2021, doi: 10.1016/j.jacc.2021.01.018.

29 P. Zhuang, J. Jiao, F. Wu, L. Mao, and Y. Zhang, "Associations of meat consumption and changes with all-cause mortality in hypertensive patients during 11.4-year follow-up: Findings from a population-based nationwide cohort," Clinical Nutrition, vol. 40, no. 3, pp. 1077-1084, Mar. 2021, doi: 10.1016/j.clnu.2020.06.040.

30 A.-F. Chiou, S.-P. Hsu, and H.-F. Hung, "Predictors of health-promoting behaviors in Taiwanese patients with coronary artery disease," Applied Nursing Research, vol. 30, pp. 1-6, May 2016, doi: 10.1016/j.apnr.2015.08.008.

31 V. Silavanich, S. Nathisuwan, A. Phrommintikul, and U. Permsuwan, "Relationship of medication adherence and QoL among heart failure patients," Heart $\mathcal{E}$ Lung, vol. 48, no. 2, pp. 105-110, Mar. 2019, doi: 10.1016/j.hrtlng.2018.09.009.

32 S. A. Hiles, P. G. Gibson, A. Agusti, and V. M. McDonald, “Treatable Traits That Predict Health Status and Treatment Response in Airway Disease," The Journal of Allergy and Clinical Immunology: In Practice, vol. 9, no. 3, pp. 1255-1264.e2, Mar. 2021, doi: 10.1016/j.jaip.2020.09.046. 
33 M. Meador, J. A. Osheroff, and B. Reisler, "Improving Identification and Diagnosis of Hypertensive Patients Hiding in Plain Sight (HIPS) in Health Centers," The Joint Commission Journal on Quality and Patient Safety, vol. 44, no. 3, pp. 117-129, Mar. 2018, doi: 10.1016/j.jcjq.2017.09.003.

34 A. E. Quinn et al., "Impact of payment model on the behaviour of specialist physicians: A systematic review," Health Policy, vol. 124, no. 4, pp. 345-358, Apr. 2020, doi: 10.1016/j.healthpol.2020.02.007.

35 S. S. Carr, A. J. Hooper, D. R. Sullivan, and J. R. Burnett, “Non-HDL-cholesterol and apolipoprotein B compared with LDL-cholesterol in atherosclerotic cardiovascular disease risk assessment," Pathology, vol. 51, no. 2, pp. 148-154, Feb. 2019, doi: 10.1016/j.pathol.2018.11.006.

36 K. K. Patel and K. Kashfi, "Lipoproteins and cancer: The role of HDL-C, LDL-C, and cholesterol-lowering drugs," Biochemical Pharmacology, p. 114654, Jun. 2021, doi: 10.1016/j.bcp.2021.114654.

37 T. Otsuka, Y. Tomata, Y. Sugawara, and I. Tsuji, "Association between weight loss since the age of 20 years and the risk of suicide death: A population-based cohort study," Journal of Affective Disorders, vol. 292, pp. 746-750, Sep. 2021, doi: 10.1016/j.jad.2021.05.127.

38 A. Saxena and E. Mendenhall, "Syndemic thinking in large-scale studies: Case studies of disability, hypertension, and diabetes across income groups in India and China," Social Science \& Medicine, p. 113503, Nov. 2020, doi: 10.1016/j.socscimed.2020.113503.

39 T. C. Dumitra et al., "The relationship of two postoperative complication grading schemas with postoperative QoL after elective colorectal surgery," Surgery, vol. 166, no. 4, pp. 663-669, Oct. 2019, doi: 10.1016/j.surg.2019.05.058.

40 B. C. Bock et al., "Exercise videogames for physical activity and fitness: Design and rationale of the Wii Heart Fitness trial," Contemporary Clinical Trials, vol. 42, pp. 204-212, May 2015, doi: 10.1016/j.cct.2015.04.007.

41 A. Rep, W. Ganzevoort, G. J. Bonsel, H. Wolf, and J. I. P. de Vries, "Psychosocial impact of early-onset hypertensive disorders and related complications in pregnancy," American Journal of Obstetrics and Gynecology, vol. 197, no. 2, p. 158.e1-158.e6, Aug. 2007, doi: 10.1016/j.ajog.2007.03.045.

42 X. Xu, Y. Rao, Z. Shi, L. Liu, C. Chen, and Y. Zhao, "Hypertension Impact on Health-Related QoL: A Cross-Sectional Survey among Middle-Aged Adults in Chongqing, China," International Journal of Hypertension, vol. 2016, pp. 1-7, 2016, doi: 10.1155/2016/7404957. 